\title{
Colorectal Lipoma
}

National Cancer Institute

\section{Source}

National Cancer Institute. Colorectal Lipoma. NCI Thesaurus. Code C5678.

A rare benign adipose tissue neoplasm arising from the wall of the colon and rectum. 